Universidade de Brasília

Faculdade de Direito

Coordenação de Graduação

Análise da Argumentação Jurídica no Supremo Tribunal Federal Direito Fundamental à Liberdade de Expressão no HC 83.996/RJ

Aluno: João de Deus Araújo Filho

Matrícula: 07/48188 
João de Deus Araújo Filho

\title{
Análise da Argumentação Jurídica no Supremo Tribunal Federal - Direito Fundamental à Liberdade de Expressão no HC 83.996/RJ
}

\author{
Monografia Final de conclusão do curso \\ de graduação apresentada como requisito \\ parcial à obtenção do título de bacharel \\ em Direito, desenvolvida sob a \\ orientação do professor Doutor Cristiano \\ Paixão.
}

Brasília, dezembro de 2011. 
João de Deus Araújo Filho

\section{Análise da Argumentação Jurídica no Supremo Tribunal Federal - Direito Fundamental à Liberdade de Expressão no HC 83.996/RJ}

Monografia Final de conclusão do curso de graduação apresentada como requisito parcial à obtenção do título de bacharel em Direito e aprovada pela seguinte banca examinadora:

Professor Doutor Cristiano Paixão

Orientador

Professor Mestre Guilherme Cintra Guimarães

Membro

Professor Mestrando Gustavo Moreira Capela

Membro

Brasília, dezembro de 2011 
Aos meus queridos pais, João e

Francisca. 


\section{Agradecimentos}

Agradeço aos meus pais, João e Francisca, que, incondicionalmente, de tudo fizeram para que eu seguisse o meu caminho acadêmico. Às minhas irmãs, Maria, Ana e Fernanda pelo carinho.

Agradeço especialmente ao professor e orientador Cristiano Paixão que tanto me inspira, apóia e, por vezes, suporta desde as disciplinas história do direito; modelos e paradigmas; direito, cinema e literatura; direito e história; projeto de iniciação científica e, finalmente, este trabalho. É importante lembrar que a inspiração de nenhum modo se resume ao mundo jurídico, mas também ao mundo da vida.

Agradeço, ainda, à professora Cláudia Roesler e aos meus colegas do projeto de iniciação científica, bem como aos amigos e colegas que, de uma forma ou outra, contribuíram apoiando a minha graduação. 
[...]

Traduzir uma parte

na outra parte

- que é uma questão

de vida ou morte -

será arte?

(Traduzir-se, Ferreira Gullar) 


\section{Resumo}

O presente trabalho analisa o direito fundamental à liberdade de expressão, bem como seus aspectos constitucionais, e observa a argumentação lançada pelo Supremo Tribunal Federal no que se refere a esse direito. Para isso, o trabalho foi dividido em duas partes. A primeira parte do trabalho busca discutir os direitos fundamentais e sua relação com a constituição e o processo de constitucionalização, além disso, alcança, especificamente, o direito à liberdade de expressão e sua intrínseca relação com a democracia. A segunda parte do trabalho traça uma análise acerca do direito fundamental à liberdade de expressão e o posicionamento do STF acerca desse direito. Para tal, faz-se uma análise acerca dos argumentos utilizados pelos ministros nos votos do acórdão do HC 83.996/RJ.

PALAVRAS-CHAVE: liberdade de expressão; direitos fundamentais; argumentação jurídica; Supremo Tribunal Federal, Habeas Corpus 83.996/RJ. 


\section{Sumário}

Introdução

PARTE 01

DIREITOS FUNDAMENTAIS: LINEAMENTOS TEÓRICOS

1. Constituição e os direitos fundamentais $\quad 12$

2. O direito fundamental à liberdade de expressão 21

PARTE 02

ARGUMENTAÇÃO JURÍDICA NO SUPREMO TRIBUNAL FEDERAL

1. O caso "Gerald Thomas"

2. Aspectos estruturais da análise - Stephen Toulmin 30

3. Análise da argumentação do acórdão - HC 83.996/RJ 35

3.1. Voto do ministro Carlos Veloso 36

3.2. Voto do ministro Gilmar Mendes 43

Conclusão 


\section{Introdução}

Os princípios fundamentais são aquisições evolutivas advindos da concepção de constituição, a qual instaura e regula o aspecto político, procedimental e material de uma democracia, e, também, determina e especifica garantias fundamentais que conferem ao indivíduo plena capacidade de autonomia.

Assim, a constituição evoca os direitos fundamentais, os quais são assim chamados devido ao seu valor para cada indivíduo. Dessa forma, significam o mínimo de proteção que a pessoa humana merece. Entre esses direitos fundamentais está o direito à liberdade de expressão. Esse direito remonta a ideia de rompimento com o antigo regime, fazendo parte, portanto, do rol de direitos fundamentais baseados no princípio da liberdade, opondo-se subjetivamente, com isso, ao jugo do Estado.

É claro que essa concepção de liberdade de expressão, até por ser um direito fundamental, ganha muito mais amplitude quando representada dentro um contexto constitucional e democrático. Contudo, não é por se tratar de um direito que se pretende pleno, ainda mais numa sociedade que passou por uma rigorosa ditadura, que se faz mais fácil a sua aplicação, ainda mais em um contexto democrático no qual direitos fundamentais podem colidir.

Dentro dessa perspectiva, é inegável a importância do direito fundamental à liberdade expressão em uma sociedade cada vez mais complexa, e que busca atingir cada vez mais os níveis de garantias sociais - direitos fundamentais e suas significações.

Além disso, é preciso apontar a importância do direito fundamental à liberdade de expressão e o seu papel como garantidor da democracia na medida em possibilita a trânsito de opiniões e ideias que tornam possíveis a participação social na representação política, bem como na crítica desse mesmo sistema. 
Esses direitos das gerações seguintes, por sua vez, implicam maior complexidade na medida em que se pretende consolidar os direitos das gerações anteriores. Dessa forma, o direito à cultura, por exemplo, imprime uma sofisticação e amplitude ao direito à liberdade de expressão.

Nesse contexto de múltiplos direitos fundamentais, é improvável que, em determinadas situações, tais direitos não se confrontem. Nessas hipóteses, a dificuldade na resolução dos casos é superada em face da constituição, a qual limita os próprios direitos que evoca.

É tratando desses aspectos teóricos importantes, mas não exaustivos, que se pretende envolver e embasar a análise de caso concreto.

Para analisar o tratamento atribuído a esse direito fundamental podemos analisar a argumentação utilizada no Supremo Tribunal Federal. Nesse sentido, escolheu-se o acórdão no HC 83996/RJ, o qual trata do caso do diretor de teatro Gerald Thomas.

Esse teatrólogo, no ano de 2003, ao final do espetáculo que dirigiu no Rio de Janeiro, foi vaiado pelo público presente no teatro. Em resposta à ovação negativa, o diretor desnudou as nádegas e mostrou-as ao público e, em seguida, simulou uma masturbação. Com isso, houve uma ação no Juizado Especial Criminal que o denunciava por ato obsceno.

Após vários habeas corpus, houve um, finalmente, no acórdão do STF que decidiu a ação. É em face desse acórdão que se fará a análise argumentativa do presente trabalho, voto por voto, no intuito de obter um entendimento acerca do tratamento atribuído ao direito à liberdade de expressão.

No acórdão é possível analisar e identificar a direção indicada pela Suprema Corte no que diz respeito ao direito de liberdade de expressão, já que dispõe sobre as estratégias jurídicas e políticas utilizadas na construção de cada voto. Trata-se, assim, de traçar uma análise em face das estruturas argumentativas, bem como do ponto 
de vista da coesão existente entre os vários argumentos, entre si, e entre esses argumentos e suas conclusões. 


\section{DIREITOS FUNDAMENTAIS: LINEAMENTOS TEÓRICOS}

\section{Constituição e direitos fundamentais}

O Direito, nos moldes contemporâneos, é essencialmente calcado em princípios consagrados na norma constitucional. Tal disposição atende a um viés teórico que entende os princípios como base que fundamenta todo o restante do sistema jurídico-constitucional.

Os princípios fundamentais fazem parte, pois, das aquisições evolutivas advindas da concepção de constituição, que instaura e regula o aspecto político, procedimental e material, de uma democracia e, também, determina e especifica garantias fundamentais jurídicas que conferem ao indivíduo plena capacidade de autonomia. Em verdade, como se percebe, a vinculação entre o aspecto político e jurídico é indispensável ${ }^{1}$. Não à toa, a constituição é tida como acoplamento estrutural de ambos os subsistemas ${ }^{2}$.

A constituição, sendo a norma máxima, é parâmetro determinante na resolução de conflitos na sociedade contemporânea. Essa sociedade possui uma cadeia de conflitos cada vez mais complexa, exigindo assim novas maneiras de resolução. E é da constituição que surge a base de resolução dos conflitos sociais, já que afirma como própria estrutura da autodeterminação do direito, além de conceber a democracia, a justiça e declarar-se dependente de princípios ${ }^{3}$.

É claro que esses direitos fazem parte de expectativas normativas sociais impregnadas na sociedade. A positivação funciona como proteção e estabilização daqueles direitos ${ }^{4}$ e, ao mesmo tempo, como redutor de complexidade em uma sociedade hiper-complexa, como a contemporânea.

Esses direitos, que são os fundamentais, são assim chamados devido ao seu valor para cada indivíduo, assim, significam o mínimo de proteção que a pessoa

\footnotetext{
${ }^{1}$ LUHMANN (1985, p. 53).

${ }^{2}$ CAMPILONGO (2002, p. 98$)$.

${ }^{3}$ CORSI (2001, p. 5).

${ }^{4}$ VERSCHRAEGEN (2002, p. 259).
} 
humana merece. Entre esses direitos fundamentais está o direito à liberdade de expressão, o qual será analisado mais aprofundadamente no decorrer do trabalho, que possui determinante importância para a realização pessoal de qualquer pessoa, individualmente, e para a sociedade como um todo, na dinâmica comunicacional.

É importante observar, contudo, que, se por um lado a constituição assegura direitos fundamentais, também é a constituição que os limita, sobretudo quando postos em confronto, em determinada situação, diversos direitos fundamentais. Nesse sentido, a idéia de absolutização de direitos fundamentais é flexibilizada.

Como exemplo, podemos observar que constituição consagra o direito fundamental à liberdade de expressão, o qual determina a livre manifestação de pensamento, sendo, entretanto, vedado o anonimato. Além disso, há outras referências à preservação da liberdade de expressão como o Art. 220, o qual determina que a manifestação do pensamento, a criação, a expressão e a informação, sob qualquer forma, processo ou veículo não sofrerão qualquer restrição, observado o disposto nesta constituição.

Esse direito não está restrito à nossa realidade constitucional, mas também aos direitos humanos no âmbito internacional, os quais representam processo histórico complementar à própria sociedade moderna diferenciada. Além disso, os direitos humanos e as liberdades fundamentais são mecanismos de proteção dessa sociedade contra o que podemos denominar de desdiferenciação ${ }^{5}$.

É importante observar essa determinação do Art. 220. No final de seu expresso, tal artigo dispõe de certa ressalva com relação aos direitos expressos por ele: [...] não sofrerão qualquer restrição, observando o disposto nesta constituiçãa. Grande valia possui para o ordenamento jurídico esse trecho do artigo acima referido. Isso expressa uma restrição da constituição para a própria constituição. É uma maneira de evitar, de certo modo, contradição em suas resoluções, ou mais, é um modo de autolimitação.

\footnotetext{
${ }^{5}$ VERSCHRAEGEN (2002, p. 258).
} 
Como demonstrado acima, essa liberdade de expressão é limitada ${ }^{6}$ pela própria constituição. Ou seja, será limitado ou controlado, o direito à liberdade de expressão quando este infringir direta ou indiretamente outros princípios, gerais (determinações mais abrangentes) ou diretos (como os demais direitos fundamentais).

Dessa forma, é inegável a relação entre constituição e os direitos fundamentais. Inclusive, é possível sustentar a ideia de que a constituição compreende a arquitetura da conformação do próprio estado, bem como dispõe os denominados direitos fundamentais.

Salvo algumas poucas exceções, os textos constitucionais compreendem, de um lado, aquilo que se pode mais classicamente definir como os critérios da separação dos poderes, a forma do Estado e as regras de transformação da própria constituição e, de outro, os chamados "direitos fundamentais"?

Dentro dessa perspectiva jurídica e, ao mesmo tempo, política, os direitos fundamentais são intrínsecos à constituição na medida em que formam conteúdo necessário à sua própria concepção conceitual - constituição moderna. Tal conceito, portanto, dispõe textos normativos de conformação e arquitetura do próprio estado, bem como de suas instituições, e, ao mesmo tempo, textos normativos denominados de direitos fundamentais.

Os primeiros são aqueles que expressam conteúdo semântico na medida em que permitem a praticabilidade de seus próprios preceitos ${ }^{8}$. Os segundos, por sua vez, são aquelas determinações esparsas de especificações, as quais serão imputadas aos diversos sistemas sociais.

Pelo contrário: a função destes direitos pode ser desenvolvida apenas $e$ exatamente porque estes não especificam de nenhum modo a praticabilidade de seus preceitos. Tal especificação é delegada aos diversos subsistemas da sociedade - a diferença entre rico e pobre, hoje, é uma questão econômica, aquela entre quem tem um diploma de estudo superior e aqueles que não o têm é decidida pelo sistema da educação, e assim em diante ${ }^{9}$.

\footnotetext{
${ }^{6}$ CORSI (2001, p. 06).

${ }^{7}$ CORSI (2001, p. 05).

${ }^{8}$ CARVALHO NETTO; SCOTTI $(2011$, p. 92)

${ }^{9}$ CORSI (2001, p. 09).
} 
Entendendo dessa maneira essa dualidade essencial entre os componentes estruturais da constituição, podemos buscar, agora, um entendimento mais específico acerca dos direitos fundamentais - suas origens e seu papel dentro da esfera social.

Podemos dizer que, de modo diferente do pensamento tradicional, a natureza racional do ser humano implica, de certa maneira, um reconhecimento de cada indivíduo como sujeito universal, aquele indivíduo que é detentor do seu próprio destino $^{10}$.

Esse homem, novo e auto-proclamado moderno, reconhece o outro em reciprocidade - na igualdade e na liberdade. Propõe-se uma nova perspectiva, diferente da visão medieval ${ }^{11}$, no intuito de traçar uma arquitetura de convivência em sociedade, a qual concebe uma convivência na igualdade de direitos. É nesse enquadramento que se consagram os denominados direitos fundamentais. Dessa forma, a consagração desses direitos pressupõe o reconhecimento de igualdade e liberdade inerentes a todos os indivíduos, os quais são chamados de direitos humanos.

A consagração dos direitos fundamentais pressupõe a exigência moral, universal e abstrata, do reconhecimento dessa igualdade e dessa liberdade como inerentes a todos os indivíduos que hoje denominamos direitos humanos e que à época os modernos conseguiram impor como o novo conteúdo semântico da antiga expressão "direito natural ${ }^{12, " ~}$

Segundo, Hesse, nas palavras de Bonavides, os direitos fundamentais buscam estruturar e manter os pressupostos elementares de uma vida na liberdade e na dignidade humana ${ }^{13}$. Por Schmitt, ainda nas palavras daquele autor, os direitos fundamentais são aqueles direitos ou garantias os quais estão escritos na carta constitucional $^{14}$, caracterizando-se, portanto, tal conceito como formal. Ainda, do ponto de vista formal, Schmitt observa que os direitos fundamentais são os direitos que receberam da constituição um grau mais elevado de garantia ou segurança - caracteriza certa imutabilidade ${ }^{15}$.

\footnotetext{
${ }^{10}$ CARVALHO NETTO; SCOTTI (2011, p. 91).

${ }^{11}$ CARVALHO NETTO; SCOTTI (2011, p. 91).

${ }^{12}$ CARVALHO NETTO; SCOTTI (2011, p. 92).

${ }^{13}$ BONAVIDES (2008, p. 560).

${ }^{14}$ BONAVIDES (2008, p. 561).

${ }^{15}$ BONAVIDES (2008, p. 561).
} 
No que se refere à visão material dos direitos fundamentais, o mesmo autor define que esses direitos variam conforme a ideologia concebida em cada estado. Dessa forma, consagra, por fim, os direitos concernentes ao homem livre, aqueles que contrapõem em face do Estado.

Os direitos fundamentais propriamente ditos são, na essência, entende ele, os direitos do homem livre e isolado, direitos que possui em face do Estado. E acrescenta: numa acepção estrita são unicamente os direitos da liberdade, da pessoa particular, correspondendo de uma lado ao conceito do Estado burguês de Direito, referente a uma liberdade, em princípio ilimitada diante de um poder estatal de intervenção, em princípio limitado, mensurável e controlável ${ }^{16}$.

Toda essa concepção dos direitos fundamentais, baseada em liberdade e dignidade, traz consigo um aspecto inerente relacionado à universalidade desses direitos como ideal da pessoa humana ${ }^{17}$. Essa percepção universal, contudo, só tomou força de manifestação significativa na Revolução Francesa, sobretudo na Declaração dos Direitos do Homem de 1789.

Não é exaustivo salientar que toda essa concepção estava dentro de um contexto de rupturas do antigo regime, e também do ordenamento jurídico ${ }^{18}$. E foram, justamente, essas rupturas os eventos significativos no processo que culminou com o que denominamos de ato constituinte.

Contudo, no que se refere a uma revolução transformadora dos aspectos jurídico e político, esse processo não se caracteriza como uma novidade tão "nova", já que, na França, o conceito de constituição - constitution - fora recepcionado do inglês.

Na realidade, não é assim tão profunda a novidade que se oculta por detrás da precondição de uma revolução do sistema político travestida de ruptura do direito conforme o direito. Em 1789, a França recepciona o conceito inglês de constitution conjuntamente com todas as suas imprecisões e, sobre essa matriz, limita-se simplesmente a discutir as dimensões da redistribuição sempre necessárias dos $\operatorname{pesos}^{19}$.

E nesse processo, que levou a um sentido de constitucionalização, os direitos fundamentais estavam inseridos paralelamente, e nunca separados. Foram

\footnotetext{
${ }^{16}$ BONAVIDES (2008, p. 561).

${ }^{17}$ BONAVIDES (2008, p. 562).

${ }^{18}$ LUHMANN (!996, p. 05).

${ }^{19}$ LUHMANN (1996, p. 06).
} 
processos que atravessaram as rupturas, por vezes causadores dessas, e se consolidaram juntamente.

Os direitos humanos, liberdades individuais, contudo, possuem uma perspectiva calcada no ideal de proteção de cada indivíduo e, incondicionalmente, estariam, geograficamente, posicionados sobre a própria sociedade e o estado ${ }^{20}$. Dessa forma, institucionalizam-se como auto-proteção da própria sociedade.

In his analysis Luhmann tries to make clear why the classical declarations - the French 'Déclaration des Droits de l'Homme et du Citoyen' (1789), the first ten amendments of the federal constitution of the United States of America (1791), the Universal Declaration os Human Rights (1948), and so on - promugate the human rights as 'fundamental' rights and freedoms, rights which are awarded 'naturally' and, as such, unconditionally'.

Os direitos fundamentais, portanto, são parte do processo evolutivo constitucional. Além disso, são parte significativa da própria essência da constituição, já que são representados positivamente em seu corpo. Não se pode, contudo, como já acenado anteriormente, observar que possuem processo evolutivo próprio, paralelo ao processo constitucional.

Com isso, é possível conceber, a partir dessas declarações, sobretudo a calcada no lema revolucionário francês, que se exprimiram os três princípios cardeais da possibilidade dos direitos fundamentais - liberdade, igualdade e fraternidade ${ }^{22}$.

Aqueles direitos referentes à liberdade foram os primeiros a fazerem parte do corpo constitucional, dessa forma inauguraram o panorama constitucional no processo histórico do ocidente. Esses direitos, que agora concebemos como sedimentados na estrutura social do ocidente, estiveram na pauta de positivação normativa de diversos países, os quais foram exaltados de maneira crescente, mas nem sempre com sucesso, conforme as particularidades de cada estado constitucional.

Se hoje esses direitos parecem já pacíficos na codificação política, em verdade se moveram em cada país constitucional num processo dinâmico e ascendente, entrecortado não raro de eventuais recuos, conforme a natureza do respectivo

\footnotetext{
${ }^{20}$ VERSCHRAEGEN (2002, p. 263).

${ }^{21}$ VERSCHRAEGEN (2002, p. 263).

${ }^{22}$ BONAVIDES (2008, p. 563).
} 
modelo de sociedade, mas permitindo visualizar a cada passo uma trajetória que parte com freqüência de mero reconhecimento formal para concretizações parciais e progressivas, até ganhar a máxima amplitude nos quadros consensuais de efetivação democrática do poder ${ }^{23}$.

É importante observar que essa tendência crescente, embora em sua concretização tenha havido certos recuos, acena para uma perspectiva aberta ${ }^{24}$, indicando sempre novas possibilidades de avanços.

Dessa forma, entende-se que há certa força que busca parar o encolhimento desses direitos e, ao mesmo tempo, suporta uma carga que aponta positivamente para a amplitude desse rol de direitos. Assim, ao observar a trajetória histórica desses direitos, pode-se constatar que foram consolidados numa perspectiva duplamente universal - no sentido de englobar todos os indivíduos; e no sentido de força expansiva dos direitos.

Em essência, os chamados direitos fundamentais relacionados à liberdade, são aqueles que se opõem ao Estado e possuem como titular o indivíduo. Além disso, esses direitos representam faculdades dos indivíduos e carregam a subjetividade como característica primordial. Pode-se dizer, ainda, que esses são os direitos que valorizam indivíduo das liberdades abstratas.

São por igual direitos que valorizam primeiro o homem-singular, o homem das liberdades abstratas, o homem da sociedade mecanicista que compõe a chamada sociedade civil, da linguagem jurídica mais usual ${ }^{25}$.

Como exemplo, podemos analisar o caso do direito à cultura, de que tanto se fala nos dias de hoje, sobretudo no que se refere aos fundos de apoio à cultura, ao incentivo tímido do Estado e etc.

A política relacionada ao direito à cultura surgiu na França no ano de 1959 sob a orientação ideológica de André Malraux ${ }^{26}$. Deu-se, então, essa política, com a criação do Ministério dos Negócios Culturais. O projeto de Malraux queria a realização do sonho francês de restituir seu gênio passado, dar vida a seu gênio presente e acolher

\footnotetext{
${ }^{23}$ BONAVIDES (2008, p. 563).

${ }^{24}$ BONAVIDES (2008, p. 563).

${ }^{25}$ BONAVIDES (2008, p. 564).

${ }^{26}$ SILVA (2001, pp.. 207-208).
} 
o gênio do mundo. Isso por meio de política cultura de proteção da arte e a promoção de novas culturas.

Mas Malraux - como nota Raymond Aron - "não amava a Política senão na história e na poesia", teria, pois que ser a expressão da V República qye se instalava na França, sob o poder do General Charles De Gaulle e a Constituição de 1958. Concebera ela um projeto de ação que se queria realizasse o sonho da França, ou seja: "restituir a vida a seu gênio passado, dar vida a seu gênio presente, e acolher o gênio do mundo" 27 .

Assim, essa política deu impulso a uma ação cultural que começou expandir-se, talvez em âmbito global, sempre buscando a ampliação das diversas esferas da cultura como artes cênicas, cinema, literatura, dança e outros. Isso, também, levou a uma distinção entre a função da educação e da cultura. A primeira ensina a conhecer as obras, a função da segunda é a de fazer $\operatorname{amar}^{28}$.

A política cultural desenvolvida por Malraux foi umas das primeiras ações no sentido de desenvolvimento cultural dentro do contexto contemporâneo. É nessa perspectiva que se pretendia a política cultural, sobretudo por esta ser um direito que assume importante papel na democracia.

Dessa forma, a cultura torna-se elemento essencial na persecução de uma democracia plena. Assim como outros direitos fundamentais, a cultura se faz necessária ao pleno exercício de cidadania. E somente a partir de política cultural do Estado essa democracia cultural pode ser realizada.

Podemos observar que esses direitos fundamentais, como o direito à cultura, sugerem, em essência, uma consolidação, e implementação, dos direitos fundamentais anteriores - os direitos de liberdade.

A democracia cultural pode-se apresentar sob três aspectos: por um lado, não tolher a liberdade de criação, expressão e de acesso à cultura, por qualquer forma de constrangimento ou de restrição oficial; antes criar condições para a efetivação dessa liberdade num clima de igualdade; por outro lado, favorecer o acesso à cultura e o gozo dos bens culturais à massa da população excluída ${ }^{29}$.

\footnotetext{
${ }^{27}$ SILVA (2001, p. 208).

${ }^{28}$ SILVA (2001, p. 208).

${ }^{29}$ SILVA (2001, p. 209).
} 
Ao analisarmos o direito ao desenvolvimento, por exemplo, perceberemos que esse direito atua, inclusive, a partir do princípio da solidariedade, e não só baseado no princípio da fraternidade.

"1. O dever de todo Estado particular de levar em conta, nos seus atos, os interesses de outros Estados (ou de seus súditos);

2. Ajuda recíproca (bilateral ou multilateral), de caráter financeiro ou de outra natureza, para a superação das dificuldades econômicas (inclusive com auxílio técnico aos países subdesenvolvidos e estabelecimento de preferências de comércio em favor desses países, a fim de liquidar déficits); e

3. Uma coordenação sistemática de política econômica."30

A partir disso, conseguindo visualizar esses importantes pontos acerca do constitucionalismo e sua relação com os direitos fundamentais, bem como suas resignificações, podemos seguir com o intuito de analisar, especificamente, o direito fundamental à liberdade de expressão e alguns de seus aspectos mais relevantes para o presente trabalho.

${ }^{30}$ BONAVIDES (2008, p. 570). 


\section{2. $O$ direito fundamental à liberdade de expressão}

O conceito de liberdade possui diversas acepções, sem contar, é claro, com a capacidade mutante de seu significado consoante as conjunturas históricas. Se observarmos, por exemplo, a liberdade exercida pelos antigos cidadãos gregos, repararemos que ela possui, comparada à de hoje, muito mais obrigações e deveres. Tratava-se de um tipo de liberdade condicionada à participação na vida pública ${ }^{31}$, que exigia uma atuação política, muitas das vezes, direta por parte de cada indivíduo livre.

Chamamos hoje de liberdade, grosso modo, a capacidade de exercer livremente a própria vontade e, ao mesmo tempo, possuir autonomia para exercer essa vontade. É claro que esse tema é inesgotável, e possui, ainda, um viés bastante filosófico, que ensejou, e até hoje enseja, um estudo sofisticado para seu tratamento.

Quando passamos a analisar o campo jurídico, o tema liberdade ganha novos contornos. A ciência do Direito, nos moldes contemporâneos, é essencialmente calcada na norma, em especial, a norma constitucional. Não raro ouvimos de muitas bocas a expressão "força da constituição". A constituição, sendo a norma máxima, fazse regra do jogo social. A sociedade contemporânea possui uma cadeia de conflitos cada vez mais complexa, exigindo assim novas maneiras de resolução de conflitos. E é da constituição que surge a possibilidade genérica de resolução dos conflitos sociais.

A constituição brasileira traz um diversificado catálogo de direitos fundamentais expressos em seu Art. $5^{\circ}$. Esses direitos são assim chamados devido ao seu valor para cada indivíduo, assim, significam o mínimo de proteção que a pessoa humana merece. Entre esses direitos fundamentais está o direito à liberdade de expressão, que possui determinante importância para a realização pessoal de qualquer indivíduo.

A liberdade de expressão remonta, conforme já afirmado, a idéia de rompimento com o antigo regime, fazendo parte, portanto, do rol de direitos

\footnotetext{
${ }^{31}$ FINLEY (1998, p. 31).
} 
fundamentais baseados no princípio da liberdade, opondo-se subjetivamente à capacidade coativa do Estado. É claro que essa concepção de liberdade de expressão, até por ser um direito fundamental, ganha muito mais amplitude quando representada dentro um contexto constitucional e democrático.

\begin{abstract}
Mesmo entre as democracias, os Estados Unidos se destacam pelo grau extraordinário em que sua Constituição protege a liberdade de expressão e a liberdade de imprensa.

[...] Segundo a Primeira Emenda à Constituição, o Estado "não pode elaborar nenhuma lei... que limite a liberdade de expressão ou a liberdade de imprensa" 32 .
\end{abstract}

Embora, também, possamos dizer que haja certo embate, na sociedade americana, no que se refere ao tratamento e aplicação dessa importante emenda constitucional. Há, assim, duas grandes linhas em debate, uma é libertária, que vê o Estado como grande adversário deste direito, e tem como ideal de regulação o mercado de idéias, no qual os agentes privados comunicam-se sem qualquer interferência do Estado. Já a outra linha seria a ativista, que concebe e, por vezes, reclama a intervenção do Estado ${ }^{33}$.

Curioso observar que essa concepção, embora esteja sacramentada na Primeira Emenda da constituição norte-americana, está refletida no artigo $5^{\circ}$ da carta constitucional democrática brasileira.

Garantiu-se, pois, no rastro da Primeira Emenda norte-americana, irrestritamente a liberdade de expressão, a qual deve, contudo, por força do "princípio da ligação da liberdade de pensamento à personalidade", estabelecido pela vedação ao anonimato, vir sempre acompanhada de identificação do autor ${ }^{34}$.

De outra sorte, podemos observar que o conceito de liberdade de expressão está muito ligado à idéia de liberdade de imprensa que, por sua vez, remonta a idéia de oposição em relação ao Estado. Seja a liberdade de imprensa, seja a liberdade de expressão, são componentes da idéia de prática, ou mesmo justiça, democrática ${ }^{35}$.

É importante observar que, quando se fala em liberdade de expressão, tendemos muito a visualizar os produtos e ações dos meios de comunicação - imprensa.

\footnotetext{
${ }^{32}$ DWORKIN (2006, p. 311).

${ }^{33}$ SAMENTO (2010, PP. 266-267).

${ }^{34}$ BORNHOLDT (2010, p. 93).

${ }^{35}$ DWORKIN (2006, p. 264).
} 
Contudo, a liberdade de expressão supera essa classificação, atinge além desses vínculos jornalísticos.

O termo liberdade de expressão será, contudo, preferido à simples liberdade de opinião, uma vez que a menção desta poderia sugerir a inexistência de uma liberdade de transmitir fatos ${ }^{36}$.

De outra sorte, é importante esclarecer, essa liberdade não pode ser restrita às palavras, assim podendo referir-se a palavras e modos de expressão corporal diversos $^{37}$ como a mímica ${ }^{38}$, que no contexto do presente trabalho é de extrema importância, conforme se passará a observar na próxima etapa.

Dentro do espectro jurídico, nos direitos fundamentais, a liberdade de expressão possui relevância significativa. A constituição Brasileira afirma o direito à liberdade de expressão ao determinar, em seu artigo $5^{\circ}$, IV, ao observar que é "livre a manifestação do pensamento, sendo vedado o anonimato", e também faz referência a esse direito em seu próprio inciso XVI: é assegurado a todos o acesso à informação e resguardado o sigilo, quando necessário ao exercício profissional. Aqui, entende-se, e vincula-se, sobretudo, o papel da mídia.

Esse direito, portanto, tutela a opinião, a convicção ${ }^{39}$, comentário, avaliação e ou julgamento sobre quaisquer assuntos e pessoas, públicas ou não.

Sendo assim, podemos observar que as condutas que são tuteladas por esse direito podem ser infinitas, e estão entremeadas em todo o sistema social. Dessa forma, não há de se negar que liberdade de expressão reflete a liberdade individual e, ao mesmo tempo, a garantia da democracia ${ }^{40}$.

A liberdade de expressão é imprescindível na conformação de um regime democrático, na medida em que sua garantia possa permitir que a vontade coletiva possa ser consolidada por meio do debate, das argumentações, dos confrontos livres de

\footnotetext{
${ }^{36}$ BORNHOLDT (2010, p.83).

${ }^{37}$ MENDES; COELHO; e BRANCO (2008, p. 360).

${ }^{38}$ BORNHOLDT (2010, p.85).

${ }^{39}$ MENDES; COELHO; e BRANCO (2008, p. 361).

${ }^{40}$ SARMENTO (2010, p. 280).
} 
ideias $^{41}$ e etc. Além disso, é preciso observar que, ao permitir que todos os cidadãos possam usufruir da possibilidade de participar, a liberdade individual está sendo garantida.

Essa concepção de liberdade de expressão como garantia da democracia constitui-se de maneira mais firme quando dentro de um contexto em que está presente um modelo de deliberativo de democracia. Tal modelo enfatiza o papel do debate público para o equacionamento das divergências, assim, partindo da premissa de que aqueles que ali atuam possam se convencer acerca de argumentos que não eram concebidos anteriormente ${ }^{42}$.

Nesse sentido, há interesse claro da democracia em arquitetar uma firme proteção ao direito fundamental á liberdade expressão, já que, no contexto democrático, é a liberdade de expressão - comunicação livre - entre os cidadãos que confere legitimidade à ordem jurídica ${ }^{43}$.

Dessa forma, é direta a relação entre liberdade de expressão e o bom funcionamento de uma sociedade democrática, já que esse modelo de sociedade prescinde de debate público dinâmico e plural. Ademais, é importante que esse debate público e plural não seja controlado nem pelo Estado, nem pelo poder econômico ou político da esfera privada ${ }^{44}$.

Conforme já acenado, outro fator importante que justifica garantia reforçada do direito fundamental á liberdade expressão é a autonomia individual. Partimos, assim, da idéia de que o ser humano é capaz de interagir comunicativamente com os demais, e essa ação é uma necessidade vital. Assim, privar o indivíduo de praticar essa comunicação é privá-lo de um dos mais importantes aspectos do ser humano.

Privar o indivíduo destas faculdades é comprometer sua capacidade de realizarse e de desenvolver-se como pessoa humana. Trata-se, portanto, de uma das mais graves violações à autonomia individual que se pode conceber, uma vez que a

\footnotetext{
${ }^{41}$ SARMENTO (2010, p. 281).

${ }^{42}$ SARMENTO (2010, p. 281).

${ }^{43}$ SARMENTO (2010, p. 282).

${ }^{44}$ SARMENTO (2010, p. 283).
} 
nossa capacidade de comunicação com o outro é certamente um dos aspectos mais essenciais da nossa própria humanidade ${ }^{45}$.

Como já acenado, vários são os dispositivos da constituição brasileira que tutelam as condutas relacionadas à liberdade de expressão. É importante observar que acaso não foi, já que, como já comentado, o direito à liberdade de expressão é essencial para realização individual. Além disso, podemos crer que muito tem que ver o papel de afastamento das ações cometidas contra esse direito à época da ditadura militar ${ }^{46}$.

Nesse sentido, o fato da constituição de 1988 conceber distintas aparições de normas as quais regulam a liberdade de expressão acena em uma direção nem tanto libertária. Ora, ao estabelecer norma, como o artigo 220, confere certa limitação ao próprio direito de liberdade expressão. Dessa forma, não imputa a liberdade de expressão em sentido libertário ${ }^{47}$, como aquela tendência norte americana. Portanto, o tratamento em relação a esse direito fundamental pode ser, por vezes, ambíguo.

Em uma análise mais estrita, por exemplo, podemos observar que, embora a constituição de 1988 tenha sido a primeira a reconhecer a liberdade de manifestação do pensamento de modo isolado, impedindo restrição por lei ${ }^{48}$, essa tendência não era clara à época da constituinte.

Veja-se, por exemplo, o dispositivo pertinente, no texto do segundo substitutivo do relator:

Art. $5^{\circ} \ldots .$.

Par. 5. É livre a manifestação do pensamento, vedado o anonimato e excluída a que incitar à violência ou defender discriminação de qualquer natureza. É assegurado o direito de resposta, proporcional ao agravo, além da indenização por dano material, moral ou à imagem ${ }^{49}$.

Dessa forma, o parágrafo $5^{\circ}$ fora desmembrado em duas partes e transformadas nos incisos IV e V do mesmo artigo. Além disso, a oração "excluída a que incitar à violência ou defender discriminação de qualquer natureza" fora excluída. Nesse sentido, após essas alterações, no rastro da Primeira Emenda norte-americana ${ }^{50}$,

\footnotetext{
${ }^{45}$ SARMENTO (2010, p. 287).

${ }^{46}$ SARMENTO (2010, p. 290).

${ }^{47}$ SARMENTO (2010, p. 282).

${ }^{48}$ BORNHOLDT (2010, p. 92).

${ }^{49}$ BORNHOLDT (2010, p. 92).

${ }^{50}$ BORNHOLDT (2010, p. 93).
} 
foi garantida irrestritamente a liberdade de expressão, mas que, conforme a própria constituição, pode ser limitada.

Aproximando-se do caso a ser analisado na próxima etapa do trabalho, podemos visualizar alguns aspectos acerca da liberdade de expressão artística, a qual abrange as artes plásticas, a música, a literatura e o teatro. Contudo, não podemos colocar essas espécies como exauridas, afinal a arte possui conceito variável segundo as contingências, conforme o entendimento do Tribunal Constitucional Alemão.

Segundo o Tribunal Constitucional Alemão, não há um conceito claramente definido de arte. Nem mesmo aqueles que se ocupam do assunto, como artistas e críticos, possuem uma sua clara definição. Portanto, o âmbito normativo não nos traz consensos suficientes ${ }^{51}$.

De outra sorte, reflete o mesmo tribunal no sentido de que seria atípica a existência de consenso num campo em que sempre busca renovação e auto-libertação de manifestações tradicionais, e que possui grande desconforto em face de convenções majoritárias $^{52}$. Dessa forma, o direito deve respeitar essas concepções e especificidades.

Nesse sentido, por ser um conceito de difícil fechamento, a expressão artística pode se materializar de diversas formas. Para averiguação, contudo, é necessário não deixar de lado o contexto em que se verifica a expressão artística.

Além disso, é possível observar a aplicação do direito, relacionada à liberdade de expressão artística, mesmo não se tratando de uma "ação" ou "conduta" no sentido artístico preparado ou ensaiado, bastando, apenas, a "ação" ou "conduta" estar dentro de um contexto específico, esse por vez caracterizando a expressão artística ${ }^{53}$.

Após analisar os argumentos da impetração - segundo a qual o objetivo do réu não foi o de ofender o "pudor sexual" da platéia, mas apenas o de demonstrar desprezo pelas suas vaias - e de cotejar a conduta supostamente criminosa com o contexto da própria peça teatral - na qual umas das atrizes, inclusive, simulava uma masturbação - ele concluiu que o ato não podia ser considerado crime, por estar inserido no "contexto da liberdade expressão, ainda que inadequada e deseducada" ${ }^{, 54}$.

\footnotetext{
${ }^{51}$ BORNHOLDT (2010, p. 102)

52 BORNHOLDT (2010, p. 103).

${ }^{53}$ GUIMARÃES (2007, p. 177).

${ }^{54}$ GUIMARÂES (2007, p. 177).
} 
É justamente esse caso que será analisado em seguida. Ou seja, um caso em que, na decisão acerca de um ato supostamente criminoso, os ministros argumentam antagonicamente acerca das intenções daquele que produziu a conduta, e também argumentam acerca do contex to em que o ato fora cometido.

O caso é interessante, como já afirmado, por estar dentro de um contexto de espetáculo artístico. Dessa forma, nos leva, ao analisar os votos dos ministros, a raciocinar a conformação final de cada voto. Isso, contudo, a seguir, será analisado minuciosa e estruturalmente, voto por voto. 


\section{ARGUMENTAÇÃO JURÍDICA NO SUPREMO TRIBUNAL FEDERAL}

1. O Caso Gerald Thomas

O caso Gerald Thomas, representado no $\mathrm{HC} \mathrm{n}^{\circ} 83.996 / \mathrm{RJ}$, é adequado para análise, no presente trabalho, na medida em podemos observar um conflito entre o que seria a moralidade pública e a liberdade de expressão.

Em janeiro de 2003, no Teatro Municipal do Rio de Janeiro, foi apresentada a ópera Tristão e Isolda, dirigida pelo diretor e teatrólogo Gerald Thomas. Após o término do espetáculo, que foi negativamente "ovacionado" com vaias pela platéia, chamou-se o diretor, que também foi vaiado. Em resposta às vaias, o diretor Gerald Thomas simulou um ato de masturbação e, em seguida, baixou as calças mostrando as nádegas ao público presente no teatro.

O Ministério Público denunciou o diretor enquadrando sua conduta no tipo penal de Ato Obsceno - art. 233 do Código Penal. A denúncia foi oferecida ao Juizado Especial Criminal. Foi impetrado Habeas Corpus à Turma Recursal do Juizado no intuito de trancar a ação penal. Segundo a defesa, a conduta do diretor não poderia ser caracterizada como ato obsceno. Contudo, a Turma Recursal do Juizado não trancou a ação penal, conforme a seguinte ementa:

EMENTA - HABEAS CORPUS - ATO OBSCENO - TRANCAMENTO DA AÇÃO PENAL POR ATIPICIDADE DA CONDUTA - EXAME DO ELEMENTO SUBJETIVO. O delito de ato obsceno se tipifica quando o agente, em lugar público, exprime manifestação corpórea, de cunho sexual, que ofende o pudor público, tendo como bem jurídico protegido a moralidade pública. Para sua configuração exige-se a presença do elemento subjetivo que é o dolo, somente ocorrendo a infração se demonstrado que o agente tinha consciência da ilicitude do ato e a intenção e vontade de atingir aquele bem jurídico. Apesar de ser possível o trancamento de ação penal por falta de justa causa quando desponta a inocência do acusado, a atipicidade da conduta ou a extinção da punibilidade, tal medida somente se justifica na hipótese de estar demonstrada de forma clara e incontestável uma destas circunstâncias, não sendo razoável que se impeça o prosseguimento do processo quando o fato narrado, em tese, é típico e a questão relativa ao elemento subjetivo reclama o exame de prova, inclusive com a oitiva de testemunhas presenciais, tudo com o escopo de se apurar, no caso concreto, se houve a violação ao bem jurídico protegido pelo tipo respectivo. 
Com isso, a defesa impetrou novo Habeas Corpus, desta vez frente ao Supremo Tribunal Federal. Por fim, houve trancamento da ação penal, não por unanimidade ou maioria de votos, mas sim por empate na votação.

O ministro Carlos Velloso, que havia deferido o trancamento da ação penal em decisão monocrática, e a ministra Ellen Gracie votaram pelo indeferimento do trancamento da ação penal. Ambos os julgadores afirmaram que a devida avaliação acerca da conduta do teatrólogo ensejava uma análise mais sofisticada, a qual seria impossível de se obter por meio de Habeas Corpus.

Em divergência, o ministro Gilmar Mendes, com decisão ratificada pelo ministro Celso de Mello, votou no sentido de trancamento da ação penal, ao entender que a conduta do diretor do espetáculo, embora deselegante e de mau gosto, não se qualificaria como ato obsceno, mas sim como uma resposta de indiferença às vais que lhe eram direcionadas.

São os votos mencionados que serão analisados no intuito de obter uma linha de comportamento da Suprema Corte Brasileira em relação à liberdade de expressão. Tais aspectos serão traçados à luz da opinião, bem como das remissões argumentativas lançadas pelos ministros votantes.

Para tal, faz-se necessário escolher e organizar uma estrutura analítica que seja capaz de descrever de maneira fragmentada a argumentação apresentada pelos julgadores nos votos a serem analisados. A estrutura utilizada foi a apresentada por Stephen Toulmin, a qual será descrita e explicada a seguir. 


\section{Aspectos Estruturais da Análise - Stephen Toulmin}

Stephen Toulmin estabeleceu uma técnica interessante no intuito de analisar argumentos contidos em determinado discurso. Tal análise se faz de maneira fragmentada, observando cada intenção contida na argumentação, no intuito de qualificá-la e entender que papel representa no discurso na qual está contida.

Dentro de uma perspectiva lógica, Toulmin acredita que um dos nossos modos de comportamento é constituído pela prática de raciocinar. Assim, nesse raciocínio, trazemos razões em favor do que fazemos, pesamos e dizemos ${ }^{55}$.

Toulmin observa que, dentro da linguagem, podemos diferenciar duas aplicações desta - a primeira é aquela em que a linguagem, por si só, atinge seu objetivo, sem que se façam necessárias razões argumentativas, como exemplos temos as sentenças imperativas; a segunda seria o uso argumentativo, a qual supõe que as intenções linguísticas fracassam ou não na medida em que possam se apoiar em argumentos e provas.

O primeiro ocorre quando as emissões lingüísticas atingem seus propósitos diretamente, sem necessidade de produzir "razões" adicionais; por exemplo, quando se dá ordem, se pede algo etc. O uso argumentativo, pelo contrário, supõe que as emissões lingüísticas fracassam ou têm êxito segundo possam se apoiar em razões, argumentos ou provas. Esse uso ocorre, por exemplo, quando se propõe uma pretensão jurídica (por exemplo, "X tem direito a receber herança"), se comenta uma execução musical, se apóia um candidato a um emprego etc ${ }^{56}$.

Nesse sentido, Toulmin sente necessário tecer uma estrutura para análise da argumentação, uma espécie de layout dos argumentos, a qual, embora simples, distancia-se da estrutura padrão da lógica - premissa maior, premissa menor e conclusão.

No intuito de tornar sua análise mais sofisticada, Toulmin observa que seria interessante comparar uma estrutura analítica à jurisprudência, que, por sua vez, concebe não somente premissas, mas sim diversos elementos, os quais possuem papéis

\footnotetext{
${ }^{55}$ ATIENZA (2006, p. 95).

${ }^{56}$ ATIENZA (2006, p. 95).
} 
diferentes dentro da argumentação, como exemplo temos os diversos eventos processuais, como testemunhas, provas materiais e até mesmo sentenças de outros casos, que podem, por vezes, estimular decisões de casos semelhantes.

A analogia com a jurisprudência pode iluminar estas questões. Nesta analogia, seriamos levados a adotar um layout mais complexo que o costumeiro, visto que as perguntas que fazemos aqui são, mais uma vez, versões mais gerais de questões familiares à jurisprudência, campo mais especializado no qual se desenvolveram muitas distinções.[...]

As declarações legais têm inúmeras diferentes funções. Petições, indício de identificação, testemunho sobre eventos em disputa, interpretações de um estatuto ou discussões de sua validade, reivindicação de isenção ou imunidade para a aplicação de uma lei, argumentos atenuantes, veredictos, sentenças; todas essas classes diferentes de proposição têm papéis específicos a desempenhar nos processos legais, e as diferenças entre elas, na prática, não são, nem de longe, insignificantes ${ }^{57}$.

Dessa forma, o autor observa que se quisermos uma estrutura imparcial na compreensão do processo lógico, teremos que empregar um padrão de elementos referenciais tão sofisticado quanto os padrões estruturais utilizados no universos do Direito.

Se tivermos de expor nossos argumentos com completa imparcialidade lógica e compreender adequadamente a natureza do "processo lógico", teremos, com certeza, de empregar um padrão de argumentos tão sofisticado, no mínimo, quanto é necessário em Direito ${ }^{58}$.

Assim, Stephen Toulmin intenta tecer uma estrutura que conceba uma relação de proximidade entre alegações e outras emissões lingüísticas que podem corroborar a integridade das alegações. Nesse sentido, busca uma estrutura que impõe a coexistência de uma premissa e os dados ou informações, os quais contribuem para fortalecer a veracidade ou validade da alegação.

Dessa forma, o autor propõe uma estrutura distinta, e mais complexa, do que aquela relação simples de lógica - se A, então B. A forma proposta por Toulmin apresenta um aspecto mais complexo e variável. A relação lógica anterior, que concebe a situação "se A, então B", determina a seguinte conclusão: se A, então, necessariamente, B. Dessa forma, a relação lógica apresentada não admite qualquer conclusão distinta de $\mathrm{B}$, havendo a situação A.

\footnotetext{
${ }^{57}$ TOULMIN (2001, p. 138).

${ }^{58}$ TOULMIN (2001, p. 138).
} 
O autor supõe, dessa forma, que para a aplicação da estrutura argumentativa, uma expressão mais crível aos olhos da realidade. Assim, tratou de conceber a expressão "presumivelmente" em vez da expressão "necessariamente".

Como exemplo, Toulmin coloca a seguinte situação:

"Harry nasceu nas Bermudas (D), já que aqueles que nascem nas Bermudas são britânicos (W), logo é britânico (C)".

No diagrama teríamos: se D, já que (W), então (C).

$\mathrm{O}$ " $\mathrm{D}$ ” seriam os dados da alegação, o "C" seria a alegação e o elemento "W" seria o que o autor chama de "garantia", a qual dá força à relação de validade entre "D” e "C". Assim, essa garantia "W" seria, por exemplo, uma lei que determina que os cidadãos que nascem em Bermudas são britânicos.

É importante ressaltar a diferença entre os dados (D) e as garantias (W). Essas últimas têm caráter geral e explanatório, no intuito somente de legitimar a relação entre os dados (D) e a alegação (C). Enquanto os dados (D) têm caráter pontual, espécie de fato. $\mathrm{O}$ autor, ainda, compara a diferença entre esses elementos com a diferença que se encontra no judiciário entre questão de fato e questões de direito.

Esta é uma das razões para distinguir entre dados e garantias; recorre-se a dados de modo explícito; e a garantias de modo implícito. Além disso, pode-se observar que as garantias são gerais, certificando a solidez de todos os argumentos do tipo apropriado, e, portanto, têm de ser estabelecidas de modo muito diferente dos fatos que apresentamos como dados. Essa distinção entre dados e garantias é semelhante à distinção que se faz, nos tribunais de justiça, entre questões de fato e questões de direito, e a distinção legal é a de fato um caso especial do caso mais geral ${ }^{59}$.

Dessa forma, teríamos uma estrutura mais complexa, já que adotamos dado (D), alegações (C) e garantias (W). Contudo, Stephen Toulmin apresenta, ainda, outros elementos a serem considerados em sua estrutura de argumentação. Tais elementos seriam as chamadas condições de exceção e refutação $(\mathrm{R})$ e as qualificadoras modais $(\mathrm{Q})$.

Qualificadores modais (Q) e condições de exceção ou refutação (R) são diferentes tanto dos dados como das garantias, e merecem lugares separados em

\footnotetext{
${ }^{59}$ TOULMIN (2001, p. 143).
} 
nosso layout. Assim como uma garantia (W) não é em si nem dado (D) nem alegação $(C)$, visto quem implicitamente faz referência a $D$ e faz referência a $C$ a saber, (1) que o passo de um para o outro é legítimo; e (2) que, por sua vez, Q e $\mathrm{R}$ são em si diferentes de $\mathrm{W}$, já que comentam implicitamente a relação entre $\mathrm{W}$ e aquele passo - assim também os qualificadores $(\mathrm{Q})$ indicam a força conferida pela garantia a esse passo, e as condições de refutação (R) indicam circunstâncias nas quais se tem de deixar de lado a autoridade geral da garantia ${ }^{60}$.

Esses elementos atingem diretamente o elemento anterior garantia (W). A garantia (W), por interferir na relação entre dados (D) e alegação (C), pode não ser considerada ou confiada pelo o interlocutor, por se tratar de garantia indevida no caso proposto, ou por ser muito genérica e etc. Dessa forma, são esses elementos que flexibilizam a força da própria garantia (W), e permitem colocar na proposição o advérbio "presumivelmente" em vez de necessariamente, além disso, pode determinar a flexibilização da garantia quando há exceções na garantia (W) apresentada.

Dessa forma, ainda utilizando o exemplo anterior, temos uma estrutura ainda mais complexa, conforme a seguir:

"Harry nasceu nas Bermudas (D), já que aqueles que nascem nas Bermudas são britânicos (W), a menos que seus pais sejam estrangeiros ou tenham adotado outra cidadania $(R)$, presumivelmente $(Q)$, é britânico ( $C$ ”.

No diagrama teríamos: se $D$, já que (W), a menos que (R), presumivelmente $(Q)$, então $(C)$.

Ainda no intuito de compor sua estrutura de argumentação, o autor adiciona o elemento denominado apoio da garantia (B). Esse elemento seria colocado como base para a credibilidade da garantia. Após a apresentação do argumento, como no exemplo anterior, se houver uma tentativa do interlocutor em testar a garantia apresentada, oferece-se o apoio da garantia (B).

Por exemplo, imaginemos a seguinte pergunta do interlocutor: por que acha que todos aqueles cidadãos que nascem em Bermudas, e que não possuem pais estrangeiros e nem tiveram alterada sua nacionalidade, são britânicos? Após esse questionamento, apresentaríamos o apoio da garantia (B): ora, porque segundo o

\footnotetext{
${ }^{60}$ TOULMIN (2001, p. 145).
} 
estatuto $\mathrm{X}$, os dispositivos legais $\mathrm{Y}$ e $\mathrm{Z}$ em vigor determinam que aqueles que nascem em Bermudas, e não possuem pais estrangeiros, nem alteraram sua nacionalidade, são britânicos.

Finalmente, caso a própria garantia seja desafiada, poderemos inserir o apoio, com os termos e as datas de decretação dos Atos do Parlamento e outros dispositivos legais que governam a nacionalidade de pessoas nascidas em colônias inglesas ${ }^{61}$.

Dessa forma, considerando a estrutura proposta pelo autor, pode-se conceber uma análise argumentativa das decisões contidas nos votos dos ministros do Supremo Tribunal Federal, referente ao HC 83.996/RJ, conforme foi proposto no início do presente trabalho.

${ }^{61} \operatorname{TOULMIN}(2001$, p. 150$)$. 


\section{Analise da Argumentação no Acórdão do HC 83.996/RJ}

No intuito de analisar as argumentações dos ministros julgadores de maneira particularizada e fragmentada, far-se-á, assim, voto por voto. Dessa forma, a análise poderá ser tecida de modo que seja possível, após tal construção, apontar argumentos, e elementos, essenciais a cada argumento proposto pelo julgador em análise.

Assim, pretende-se uma análise minuciosa das argumentações apresentadas por cada julgador, considerando, claro, ainda que apenas do ponto de vista lógico - estrutural, a teoria concebida por Stephen Toulmin, conforme já mencionado e explanado.

Dessa forma, serão analisados, cuidadosamente, os votos dos ministros Carlos Velloso e Gilmar Mendes. O voto da ministra Ellen Gracie, contudo, não terá tópico específico, já que seguiu o entendimento do ministro Carlos Velloso, embora tenha aparecido, de certa forma, na confirmação de voto, conforme a seguir:

Considero que a exposição, pouco edificante e esteticamente questionável não ultrapassa, no entanto, segundo concluiu o eminente Ministro Gilmar Mendes creio que talvez também o faça o juiz encarregado da instrução -, os limites de uma reação grosseira em relação às vaias do público, que é a única e maior razão de existência das artes cênicas. Figuras bem mais qualificadas - refiro-me apenas a Victor Hugo na estréia de Ernani, onde houve inclusive uma batalha campal adotaram postura de humildade diante daqueles que não compreenderam, na época, as inovações introduzidas em suas criações.

De acordo com o eminente Relator, entendo que a questão ficará bem dirimida no primeiro grau de jurisdição, não cabendo, desde logo, abortar a investigação que se procede ${ }^{62}$.

Portanto, seguem as análises do votos.

\footnotetext{
${ }^{62}$ Supremo Tribunal Federal, HC no 83.996/RJ, f. 356).
} 


\subsection{Voto do ministro Carlos Velloso}

Inicialmente temos que considerar que a tese de defesa do Habeas Corpus intentava desqualificar a conduta do diretor e teatrólogo, ao simular uma masturbação e mostrar as nádegas ao público, como ato obsceno, descrito no art. 233 do Código Penal. Assim, trancar-se-ia a ação penal.

Embora inicialmente o ministro Carlos Velloso tivesse concedido a liminar para o trancamento da ação em decisão monocrática, seu voto no acórdão determinaria o não trancamento da ação penal. Segundo o ministro, os fatos descritos na denúncia indicavam, ao menos em tese, a conduta de ato obsceno. Dessa forma, a ação deveria prosseguir, já que o Habeas Corpus não seria instrumento processual adequado para a avaliação da conduta.

É claro que o exame dos fatos, nos estreitos limites do processo de habeas corpus, não é feito de forma aprofundada. Ele é feito, simplesmente, para que se verifique se, de tais fatos, decorre a ocorrência de crime em tese, o que é bastante para que a denúncia ou a queixa seja recebida ${ }^{63}$.

É com esse argumento - de que se o fato descrito caracterizar, ao menos em tese, a conduta de ato obsceno não poderá ser trancada a ação penal, que o ministro Carlos Velloso se vale para não votar a favor do trancamento da ação penal.

Podemos, então, descrever a proposição do ministro Carlos Velloso da seguinte maneira, considerando a estrutura proposta por Toulmin:

Se a conduta do agente, ainda que em tese, configurar crime (D), então não pode haver trancamento da Ação Penal (C).

Nesse sentido, poderíamos indagar, frente à proposição do ministro julgador, que tipo de garantia haveria para tal proposição.

O ministro Carlos Velloso, conforme podemos observar no voto, baseou sua garantias em dois seguimentos. $\mathrm{O}$ primeiro seguimento apresentado pelo ministro

\footnotetext{
${ }^{63}$ Supremo Tribunal Federal, HC no 83.996/RJ, f. 337.
} 
seria a jurisprudência do próprio tribunal, ou seja, elencou diversas decisões que aplicariam, em tese, a casos semelhantes.

"EMENTA - s Habeas Corpus. Trancamento de ação penal por falta de justa causa.

- Se o fato descrito na denúncia constitui crime em tese, não é o habeas corpos meio idôneo para trancar-se a ação penal por falta de justa causa que só poderia ser apurada pelo exame aprofundado da prova.

Recurso ordinário a que se nega provimento."

RHC 56.593/DF.

("D.J." de 11.12.78) (44 $^{64}$

"Habeas corpus. Trancamento da ação penal. Falta de justa causa. Código Penal, artigo 171. O habeas corpus não enseja o exame aprofundado de provas, para se afirmar, desde logo, se o réu é, ou não, inocente. Diante dos fatos descritos na denúncia, não é possível, prima facie, recusar sua tipificação como ilícito criminal. Se esse fatos são verdadeiros, ou não; se existiria, apenas, questão de direito civil, somente será possível concluir, ultimada a colheita de provas, em instrução contraditória. Recurso desprovido." (RTJ 113/1.017) ${ }^{65}$.

"EMENTA: PENAL. PROCESSUAL PENAL. 'HABEAS CORPUS'. DENÚNCIA. AÇÂO PENAL. TRANCAMENTO. IMPOSSIBILIDADE. Lei 5.250/67. Arts. 21 e 22, c.c. art. 23, II.

I - Denúncia que atende aos requisitos do art. 41 do CPP.

II - A jurisprudência desta Corte firmou-se no sentido de que não se tranca a ação penal se a conduta descrita na denúncia configura, em tese, crime.

III - H.C. Indeferido". ("D.J" de 25.8.2000) ${ }^{66}$

HC $72.731 /$ SP.

"EMENTA: Habeas corpus.

1) Direito que se invoca, em habeas corpus, ao desnudamento total de busto feminino nas praias;

2) $\mathrm{O}$ que a lei tutela, no crime definido no objetivamente considerado, pouco importando a concepção pessoal do agente a respeito da obscenidade da ação que praticou ou pretende praticar;

3) Compete à autoridade pública aferir o sentimento médio de pudor coletivo e fazê-lo respeitado através do seu poder de polícia;

4) Recurso ordinário desprovido". ("DJ" de 04.04 .73$)^{67}$

RHC 50.828/SP.

O voto do ministro Carlos Velloso, portanto, em seu primeiro segmento, no intuito de dar garantia (W) à sua proposição, elencou as decisões acima transcritas. Em seu segundo seguimento de garantia (W), o ministro citou trechos doutrinários, do autores Nelson Hungria e Magalhães Noronha, acerca da temática de crime em tese, conforme a seguir:

\footnotetext{
${ }^{64}$ Supremo Tribunal Federal, $\mathrm{HC}$ n ${ }^{\circ} 83.996 / \mathrm{RJ}$, f. 337.

${ }^{65}$ Supremo Tribunal Federal, $\mathrm{HC}^{\mathrm{o}}$ 83.996/RJ, ff. 337-338.

${ }^{66}$ Supremo Tribunal Federal, $\mathrm{HC}$ n ${ }^{\circ} 83.996 / \mathrm{RJ}$, f. 338.

${ }^{67}$ Supremo Tribunal Federal, HC no $83.996 /$ RJ, ff. 340-341.
} 
Leciona Hungria que, para configuração do crime, não é necessária a intenção específica de ofender o pudor público, nem que "o ato represente uma expansão erótica ou vise à excitação da lascívia alheia: desde que, sob o prisma objetivo, se apresente em colisão com o pudor público, ou idôneo a suscitar o sentimento comum de vergonha (verecundia), pouco importa que o agente, embora deva ter consciência disso, haja procedimento, por exemplo, jocandi animo ou demonstrandi causa, ou para exercer uma vingança, sem qualquer intuito de lubricidade. Acrescenta que, por se tratar de crime de perigo, "basta a possibilidade de ofensa ao pudor público, ainda que esta não seja a intenção do agente" (Nelson Hungria, "Comentários ao Cód. Penal", Forense, 1940, $4^{\mathrm{a}}$ ed., $\mathrm{VIII} / 310)^{68}$.

“(...)

Já dissemos que o bem jurídico é o pudor sexual da sociedade e, portanto, ato obsceno que ofende necessita também ser sexual, devendo, contudo, o qualificativo ser tomado em sentido amplo, para compreender não só os atos normalmente sexual, ambos ofendendo o pudor público.

Falando-se em ato sexual, é mister ter presente não ser imprescindível que ele sirva ao desafogo da luxúria ou sensualidade do agente, como aliás, já se disse no atentado violento ao pudor público, pouco importando o móvel do agente: lubricidade, gracejo, vingança, etc." (Magalhães Noronha, "Direito Penal", Saraiva, $\left.1961,3^{\circ} / 377\right)^{69}$

Dessa forma, podemos observar que o ministro Carlos Velloso traçou a garantia (W) de seu argumento com base na jurisprudência e na doutrina. Apresentou, ainda, um certo início de discussão acerca da relação da conduta do agente e as questões históricas e sociais, as quais englobam o tema da evolução cultural e sua relação com a nudez humana.

É certo, tal como afirmado pela impetração, que, em razão da evolução cultural, a nudez humana tem-se apresentado constantemente nos veículos de comunicação, mas nem por isso em sido considerada ofensiva ao pudor público $^{70}$.

Assim, haveríamos de esperar uma direção argumentativa no sentido de flexibilização do entendimento em face da conduta de ato obsceno. Além disso, o próprio ministro, no mesmo parágrafo, trata da questão do contexto e conduta, a qual pode possuir intenções distintas conforme o contexto em que se apresenta.

[...]. No entanto, mesmo tendo isso em conta, bem como o local e circunstâncias em que a conduta foi praticada - interior de um teatro, às 2:00h $[\ldots]^{71}$

Contudo, o ministro Carlos Velloso entendeu que, ainda assim, mostradas e consideradas essas questões de cunho histórico e social, bem como as relações entre

\footnotetext{
${ }^{68}$ Supremo Tribunal Federal, HC no 83.996/RJ, ff. 339-340.

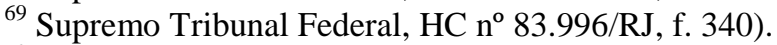

${ }^{70}$ Supremo Tribunal Federal, HC no 83.996/RJ, f. 341).

${ }^{71}$ Supremo Tribunal Federal, HC no ${ }^{\circ}$ 33.996/RJ, f. 341).
} 
contexto e conduta, seria prematuro concluir que a conduta do paciente, praticada fora do contexto teatral, não teria atingido o pudor das pessoas.

Novamente o ministro julgador firmou-se na garantia do seu argumento, observando que a questão não poderia ser resolvida sem que houvesse a instrução processual, a qual poderia valer-se de outros elementos no intuito de provar ou não a ocorrência do delito.

Somente ao final da instrução é que o Juizado poderá decidir, com base, inclusive, em novos elementos que forem colhidos, sobre a ocorrência ou não do delito ${ }^{72}$.

Ainda tratando do aspecto estrutural do argumento do ministro Carlos Velloso, podemos considerar as ressalvas apresentadas pelo julgador, acerca da evolução cultural e da conduta dentro de um contexto específico, como os elementos qualificadora modal $(\mathrm{Q})$ e condição de exceção e refutação $(\mathrm{R})$, ou seja, seriam os elementos aptos a atribuir certa flexibilidade à garantia (W) concedida entre os dados (D) e a alegação (C).

Nesse sentido, podemos observar que, por um lado, o ministro Carlos Velloso destaca argumentos que direcionam sua decisão no sentido de denegação do Habeas Corpus, ou seja, argumenta que a questão não poderia ser resolvida por meio desse instrumento processual.

Por outro lado, o ministro julgador suscitou a discussão acerca do contexto histórico e o contexto em que ocorreu a conduta, que, de certa forma, afeta, ou flexibiliza, a própria argumentação.

Ainda assim, demonstrando flexibilização à sua argumentação, o ministro Carlos Velloso optou por denegar o pedido do impetrante. Dessa forma, o ministro apresenta seu argumento, ou seja, dados (D), a alegação (C), as garantias (W), bem como suas flexibilizadoras (Q e (R).

\footnotetext{
${ }^{72}$ Supremo Tribunal Federal, HC no $83.996 /$ RJ, f. 341).
} 
Contudo, ao denegar o instrumento de Habeas Corpus, implicitamente, o ministro concebe a posição de que, ainda que haja essas flexibilizadoras, tais não seriam suficientes para limar sua garantia (W) e, conseqüentemente, a relação de validade entre os dados (D) e a alegação (C).

Sendo essa a configuração argumentativa apresentada pelo ministro Carlos Velloso, e a análise sobre tal configuração apresentada, cabe indagar se as garantias, jurisprudência elencada, teriam força suficiente para segurar a relação de validade de seus argumentos.

Assim, podemos analisar os casos apresentados na jurisprudência elencada para fortalecer a argumentação. Os três primeiros casos apresentados pelo ministro, RHC 56.593/DF - 1978, RTJ 113/1.017 e o HC 72.731/SP - 2000, refletem apenas o significado de aplicação direta da impossibilidade de resolução do processo em âmbito de Habeas Corpus, ou seja, havendo a conduta, ou crime em tese, deverá haver a instrução processual.

O outro caso apresentado pelo ministro Carlos Velloso, RHC 50.828/SP 1973, traz aspectos mais claros e aptos a serem analisados. Trata, como os outros casos apresentados, de Habeas Corpus, o qual também foi denegado. Contudo, esse caso, no que se refere à matéria em discussão, trata de questão também referente à moralidade pública.

O RHC 50.828/SP, elencado pelo ministro Julgador, refere-se ao desnudamento total do busto feminino em praias, também conhecido como top less. $\mathrm{O}$ acórdão elencado afirma que, de modo algum, cabe, ou importa, aferir a intenção do agente, e que somente o poderia público pode mensurar o sentimento médio de pudor coletivo. Assim, tal sentimento médio de pudor deveria ser respeitado em face do poder de polícia.

Dessa forma, analisando, e comparando, o caso em tela e o caso do RHC 50.828/SP, podemos observar que ambos tratam de condutas dentro de seus contextos específicos e, claro, imersos, cada um, em suas conjunturas históricas. Essas conjunturas trazem diversos aspectos para cada caso, já que cada contexto histórico é 
composto de um conjunto de hábitos e costumes próprios, os quais, sim, podem revelar de maneira muito minuciosa o pensamento político, e jurídico, de seu tempo.

O caso do top less ocorreu no início da década de setenta, ou seja, período em que a sociedade brasileira apresentava um aspecto, no que se refere aos direitos individuais, como os de liberdade de expressão, muito tímido e limitado em face do autoritarismo político que vencia à época ${ }^{73}$.

Assim, a utilização desse precedente, como elemento de garantia (W) da argumentação do ministro Carlos Velloso, pode parecer anacrônico e, talvez, incoerente dentro do aspecto de igualdade que se pretende no contexto atual.

Ao tratar os casos da mesma maneira, sem que haja quaisquer discussões acerca dos contextos políticos referentes a cada caso, o que se observa é uma vinculação histórica repleta de ajustamentos impostos por tal vinculação. Tais ajustamentos colocariam a decisão tomada dentro de uma mesma memória histórico-jurídica, sem que houvesse uma lembrança das próprias diferenças históricas de cada contexto jurídico.

Dessa forma, o voto do ministro Carlos Velloso incidiu de maneira a desconsiderar os contextos, ou pelo menos desconsiderou a distância entre os contextos não suscitados na discussão acerca da conduta e seu contexto ${ }^{74}$.

Importa observar, ainda, que ao denegar o Habeas Corpus, o ministro Carlos Velloso decidiu não decidir, ou seja, o não trancamento da ação faria com que houvesse a instrução processual na instância única do Juizado Especial.

Além disso, cabe considerar, para a análise, que embora o ministro Carlos Velloso tenha afirmado que não seria o caso adentrar na matéria, e ainda o tenha feito, após o voto do ministro Gilmar Mendes, o qual apresentou um discussão adentrando na matéria de fato, aquele ministro aditou seu voto concordando com as argumentações do

\footnotetext{
${ }^{73}$ GUIMARÃES (2007, p. 185).

${ }^{74}$ GUIMARÃES (2007, p. 180).
} 
último. Contudo, afirmou que não poderia votar da mesma maneira em face dos limites do instrumento processual ${ }^{75}$.

Dessa forma, poderia, novamente, acontecer do processo retornar a julgamento no Supremo Tribunal Federal, o que, na prática, haveria somente um adiamento de julgamento de decisão final.

Interessante observar que, ao denegar o Habeas Corpus em face de seus supostos limites processuais, o julgador permite-se, objetivamente, não decidir e, ao mesmo tempo, não adentrar na discussão da matéria, embora na prática o faça ${ }^{76}$.

\footnotetext{
${ }^{75}$ Supremo Tribunal Federal, $\mathrm{HC}$ n ${ }^{\circ} 83.996 /$ RJ, f. 354).

${ }^{76}$ GUIMARÃES (2007, p. 179).
} 


\subsection{Voto do ministro Gilmar Mendes}

O ministro Gilmar Mendes, de modo diferente do seu colega referido anteriormente, decidiu em favor do impetrante, concedendo, assim, ordem para o trancamento da ação penal.

Podemos indicar, inicialmente, que o ministro Gilmar Mendes, diferente do voto do relator, não considerou a conduta do agente como a descrita no tipo penal de ato obsceno. Segundo o ministro, tratou-se de uma manifestação deseducada e de mau gosto, uma espécie de protesto em reação ao comportamento do público que assistia seu espetáculo.

"No caso em apreço, ainda que se cuide, talvez, de manifestação deseducada e de extremo mau gosto, tudo está a indicar um protesto ou uma reação provavelmente grosseira - contra o público",77.

Ao não considerar a conduta do agente como ato obsceno, conforme insinua o instrumento de Habeas Corpus, o ministro concebe a argumentação de que tal instrumento deveria ser concedido e, conseqüentemente, haveria o trancamento da ação penal.

Desse modo, temos que, do ponto de vista estrutural, o argumento do ministro Gilmar Mendes poderia ser reproduzido, para facilitar a análise fragmentada, nos seguintes aspectos:

Se a conduta do agente não configura crime, e sim mera reação deseducada (D), então deverá haver trancamento da Ação Penal (C).

Com isso é possível esclarecer os argumentos lançados pelo ministro no intuito de descaracterizar a conduta do agente como ato obsceno e, assim, esclarecer de que modo se propõe a garantia (W) do seu argumento, que fortalece e valida a relação entre os dados (D) e a alegação (C).

Inicialmente, o ministro Gilmar Mendes afirma que a conduta do agente deu-se dentro de um contexto específico, o do espetáculo teatral, e que nesse contexto,

\footnotetext{
${ }^{77}$ Supremo Tribunal Federal, HC no $83.996 /$ RJ, f. 348).
} 
observando do que se tratava a peça, a conduta em discussão não representava ato obsceno.

Para validar essa argumentação, o ministro oferece um texto do Manual de redação da Presidência da República, o qual trata da necessidade de não atribuir às leis fundamentos objetivos, conforme a seguir:

"É certo que a lei exerce um papel deveras relevante na ordem jurídica do Estado de Direito. Assinala-se, porém, que os espaços não ocupados pelo legislador não são dominados pelo caos ou pelo arbítrio.

Embora a competência para editar normas, no tocante à matéria, quase não conheça limites (universalidade da atividade legislativa), a atividade legislativa é, e deve continuar sendo, uma atividade subsidiária. Significa dizer que o exercício da atividade legislativa está submetido ao princípio da necessidade, isto é, que a promulgação de leis supérfluas u iterativas configura abuso do poder de legislar. É que a presunção de liberdade, que lastreia o Estado de Direito democrático, pressupõe um regime legal mínimo, que não reduz e não restrinja, imotivada ou desnecessariamente, a liberdade de ação no âmbito social, devendo mesmo ser reconhecida a inconstitucionalidade das normas que estabelecem restrições dispensáveis." (MENDES, Gilmar Ferreira; FOSTER JÚNIOR, Nestor José. Manual de redação da Presidência da República. 2. ed. rev. e atual. Brasília: Presidência da República, 2002, p. 87)

Afirma o ministro que se essas limitações se dão em âmbito geral das leis, ainda mais, tem-se razão para serem aplicadas à legislação penal. Além disso, o ministro apresenta jurisprudência do próprio Superior Tribunal Federal, que traz a discussão acerca da diferença entre "obscenidade e pornografia".

\begin{abstract}
“Obscenidade e pornografia. O direito constitucional de livre manifestação do pensamento não exclui a punição penal, nem a repressão administrativa de material impresso, fotografada, irradiado ou divulgado por qualquer meio, para divulgação pornográfica ou obscena, nos termos e forma da lei. À falta de conceito legal do que é pornográfico, obsceno ou contrário aos bons costumes, a autoridade deverá guiar-se pela consciência de homem médio de seu tempo, perscrutando os propósitos dos autores do material suspeito, notadamente a ausência, neles, de qualquer valor literário, artístico, educacional ou científico que o redima de seus aspectos mais crus e chocantes. A apreensão de periódicos obscenos cometida ao Juiz de Menores pela Lei de Imprensa visa à proteção de crianças e adolescentes contra o que é impróprio à sua formação moral e psicológica, o que não importa em vedação absoluta do acesso de adultos que os queiram ler. Nesse sentido, o juiz poderá adotar medidas razoáveis que impeçam a venda aos menores até o limite de idade que julgar conveniente, desses materiais, ou a consulta dos mesmos por parte deles." (RMS 18.534, Rel. Min. Aliomar Baleeiro, RTJ 47/787) ${ }^{78}$
\end{abstract}

Além dessa construção argumentativa, elencada pelo ministro Gilmar Mendes, nas palavras de Aliomar Baleeiro, que suscitou a discussão acerca da diferença

\footnotetext{
${ }^{78}$ Supremo Tribunal Federal, HC no 83.996/RJ, ff. 351-352)
} 
entre o que é obsceno e o que é pornográfico, aquele ministro apresentou, ainda, o que falou esse ministro acerca da variação do conceito de obsceno no tempo e no espaço.

Dessa forma, o ministro Gilmar Mendes trouxe, nas palavras de Aliomar Baleeiro, a idéia de variação dos conceitos, sobretudo os de condutas sociais, no tempo e no espaço, conforme a seguir:

\begin{abstract}
"Mas o conceito de 'obsceno', 'imoral', 'contrário' aos bons costumes é condicionado ao local e à época. Inúmeras atitudes aceitas no passado são repudiadas hoje, do mesmo modo que aceitamos sem pestanejar procedimentos repugnantes às gerações anteriores. A Polícia do Rio, há 30 ou 40 anos não permitia que um rapaz se apresentasse de busto nu nas praias e parece que só mudou de critério quando o ex- Rei Eduardo VIII, então príncipe de Gales assim se exibiu com o irmão em Copacabana. O chamado bikini (ou 'duas peças') seria inconcebível em qualquer praia do mundo ocidental, há 30 anos.

Negro de braço dado com branca em público, ou propósito de casamento entre ambos, constituía crime e atentado aos bons costumes em vários Estados norteamericanos do sul, até um tempo bem próximo do atual." (RTJ 47/790) ${ }^{79}$
\end{abstract}

Assim, é possível observar a análise comparativa feita pelo ministro Gilmar Mendes acerca da aplicação de conceitos. Tais conceitos, em sua aplicação, devem ser embebidos numa composição histórica e social, no intuito de não proceder tal aplicação sem que haja considerações acerca da própria memória do conceito.

É certo, e significativo, não só a capacidade, mas a vocação mutante dos conceitos, ainda mais os que permeiam o sistema social, o qual, vivo, transforma os hábitos e costumes e, ao mesmo tempo, transforma-se, ligado simbioticamente aos hábitos e costumes, constantemente conceituando-se.

É claro que dessa forma temos que considerar sempre o que representava um conceito em outros contextos históricos. É justamente essa consideração que permite o contraste e a própria análise do conceito atual. Não há que se falar em construção analítica sem considerar o contexto, o tempo, a memória ${ }^{80}$.

O ministro Gilmar Mendes elenca, ainda, a opinião de Evandro Lins Silva, tratando do mesmo julgado, acerca da variação do conceito de obscenidade no tempo.

"O conceito de obscenidade é variável no tempo e no espaço. O que era considerado obsceno, há bem pouco tempo, deixou de o ser, com a mudança de

\footnotetext{
${ }^{79}$ Supremo Tribunal Federal, $\mathrm{HC} \mathrm{n}^{\text {o }}$ 83.996/RJ, f. 352).

${ }^{80}$ GUIMARÃES (2007, p. 185).
} 
costumes e o conhecimento que a juventude passou a ter de problema que lhe eram proibidos estudar e conhecer, até recentemente." (RTJ 47/797) ${ }^{81}$

Assim, o ministro Gilmar Mendes, ao conceber as palavras de Evandro Lins e Silva, mais uma vez toca na questão da necessidade de consideração do contexto ao aplicar-se um conceito. Impõe como garantia de sua argumentação, a idéia de que não se trata de ato obsceno a conduta do agente, já que seu comportamento deve ser analisado dentro de uma perspectiva contextual específica.

Temos, dessa forma, uma orientação de que a garantia (W) argumentativa usada pelo ministro Gilmar Mendes é compreendida, principalmente, pela consideração do contexto na conduta do agente. Assim, a garantia é essa consideração pela jurisprudência, dentro do próprio Supremo Tribunal Federal.

$\mathrm{O}$ ministro ressaltou o aspecto do contexto teatral em que se concebeu a conduta do agente. Segundo o ministro, a conduta do agente vinculava-se ao contexto, já que em cenas do espetáculo havia insinuação de masturbação.

\footnotetext{
“Com efeito, não se pode olvidar o contexto no qual se verificou o ato incriminado.

O roteiro da peça, ressalte-se, envolveu até uma simulação de masturbação. Estava-se diante de um público adulto, às duas horas da manhã, no Estado do Rio de Janeiro.

Difícil, pois, nesse contexto admitir que a conduta do paciente tivesse atingido o pudor público",
}

$\mathrm{O}$ voto do ministro Gilmar Mendes adentrou, no intuito de conceber sua argumentação, na matéria de fato do caso. Trilhou discussão acerca da capacidade mutante do conceito de ato obsceno e, como garantia, trouxe as perspectivas de outros juristas acerca do mesmo tema.

Além disso, o ministro julgador teceu comentários acerca da liberdade de expressão, direcionando a conduta do agente no sentido de, embora deseducada e de mau gosto, mera contra-reação à reação da platéia em face das cenas do espetáculo. Assim, tal conduta do agente - simular masturbação e mostrar as nádegas ao público configuraria ação de livre pensamento, a qual foi motivada pela reação do público ${ }^{83}$.

\footnotetext{
${ }^{81}$ Supremo Tribunal Federal, HC no $83.996 / R J$, ff. 352-353).

${ }^{82}$ Supremo Tribunal Federal, HC no ${ }^{\circ} 83.996 / R J$, ff. 349-350).

${ }^{83}$ GUIMARÃES (2007, p. 180).
} 
A rigor, um exame objetivo da querela há de indicar que a discussão está integralmente inserida no contexto da liberdade de expressão, ainda que inadequada e deseducada ${ }^{84}$.

De outra sorte, cabe salientar o disposto pelo ministro Gilmar Mendes acerca subsidiariedade da ação legislativa, sobretudo em tratando-se de matéria penal. Assim, o ministro concebe a idéia de que não há para tudo uma configuração de tipo. De certa forma, observou-se na discussão acerca da moralidade e do direito.

Segundo o ministro há outras esferas, que não a judicial, que poderiam tratar, ou reprovar moralmente, a conduta do agente. Dessa forma, em "explicação", o ministro observou que há de se ter cautela no intuito de não criminalizar as condutas que podem ser tratadas de outra maneira, que não a penal ${ }^{85}$.

Portanto, devemos ter, talvez, uma cautela para não tentar criminalizar as condutas ou solver, mediante o direito penal, conflitos que podem ser resolvidos de outra maneira por uma sociedade madura ${ }^{86}$.

Sendo assim, o ministro julgador fechou sua argumentação no sentido de conceder o Habeas Corpus, trancando, portanto a ação penal. É importante ressaltar o procedimento, inclusive argumentativo, utilizado por esse ministro ao adentrar na questões de fato para colocar-se frente ao ato de decidir. Não se sentiu, portanto, limitado pelo instrumento processual a não decidir naquele momento.

\footnotetext{
${ }^{84}$ Supremo Tribunal Federal, HC n ${ }^{\circ}$ 83.996/RJ, f. 350).

${ }^{85}$ GUIMARÃES (2007, p. 183).

${ }^{86}$ Supremo Tribunal Federal, HC no ${ }^{\circ} 83.996 /$ RJ, f. 358).
} 


\section{Conclusão}

O julgamento do Habeas Corpus 83.996/RJ terminou empatado. O ministro Carlos Velloso, conforme vimos anteriormente, votou no sentido do não trancamento da ação penal, argumentando que havia crime em tese, e que dúvidas não poderiam ser dirimidas nos limites do instrumento processual. A ministra Ellen Gracie votou conforme o entendimento do ministro relator Carlos Velloso.

A decisão, que ficou empatada, foi decidida com o voto do ministro Gilmar Mendes, o qual foi seguido pelo ministro Celso de Mello. A principal argumentação do ministro votante foi no sentido de descaracterização da conduta do agente como ato obsceno. Segundo o ministro, a conduta, dentro do contexto teatral, seria mera reação deseducada, do agente em face o comportamento do público ao final do espetáculo.

Em se tratado de questão penal, havendo empate, a decisão é favorável ao réu. Dessa forma, a ação penal contra o diretor e teatrólogo Gerald Thomas foi extinta.

Interessante é observar que a ação penal foi trancada frente a um empate na votação. Mesmo tratando-se de direito que poderia levar o agente a uma punição penal, e ainda, conforme suscitado em um dos votos, tratando-se de direito de liberdade de expressão em discussão, houve votos que decidiam não decidir, e, ainda, voto que demonstrou uma fundamentação anacrônica, trazendo à memória do direito, como fundamentação do próprio direito, costumes e decisões advindos de tempos de autoritarismo.

É possível constatar, na presente pesquisa, um viés ainda heterogêneo no que diz respeito ao entendimento da Suprema Corte brasileira em relação ao direito fundamental à liberdade de expressão. De um lado temos uma perspectiva ainda baseada em um ideal autoritário; de outro temos uma postura progressista no que concerne à democracia na realização desse direito fundamental: liberdade de expressão. 


\section{BIBLIOGRAFIA}

AZEVEDO, Rodrigo Ghiringheli. "Estado e Direito como sistemas autopoiéticos: uma abordagem da teoria de sistemas de Niklas Luhmann”. Laclau e Luhmann: pós fundacionismo, abordagem sistêmica e as organizações sociais. Org. Léo Peixoto Rodrigues e Daniel de Mendonça. Porto Alegre: EDIPUCRS, 2006.

ATIENZA, Manuel. As Razões do Direito - Teorias da Argumentação. São Paulo. Landy Editora, 2003.

BAUDRILLARD, Jean. Simulacros e Simulações. Lisboa: Editora Relógio D’água, 1991.

BARBOSA, Leonardo Augusto de Andrade. Mudança constitucional, autoritarismo e democracia no Brasil pós 1964. Brasília: Tese de Doutorado, Universidade de Brasília Faculdade de Direito, 2009.

BIGLIAZZI, Renato. A Constituição Domada: Democracia e o Conselho de Comunicação Social. UnB, 2007.

BONAVIDES, Paulo. Curso de Direito Constitucional. Malheiros Editores Ltda. São Paulo, 2008.

BORNHOLDT, Rodrigo Meyer. Liberdade de Expressão e Direito à Honra: uma nova abordagem no direito brasileiro. Joinville, SC: Bildung, 2010.

CAIXETA, Sebastião V. (Org.). Vinte anos da Constituição Cidadã. $1^{\mathrm{a}}$ ed. São Paulo: LTr, 2009, p. 19-36.

CAMPILONGO, Celso Fernandes Campilongo. Política, Sistema Jurídico e Decisão Judicial.São Paulo. Editora Max Limonad, 2002.

CORSI, Giancarlo. Sociologia da Constituição. Trad. Juliana N. Magalhães. Revista da Faculdade de Direito da Universidade Federal de Minas Gerais. № 39. Belo Horizonte: UFMG, janeiro-junho de 2001.

DWORKIN, Ronald. O direito da liberdade: a leitura moral da Constituição norteamericana. Tradução: Marcelo Brandão Cipolla; revisão técnica: Alberto Alonso Muñoz. São Paulo: Martins Fontes, 2006. 
Liberty and Pornograpgy. The New Your Review of Books -

On line - http://www.nybooks.com/articles/archives/1991/aug/15/liberty-andpornography/ or (http://www.nybooks/articles/3175) - Acces. 08. Dec. 2011.

Women and Pornography. The New Your Review of Books -

On line - http://www.nybooks.com/articles/archives/1993/oct/21/women-andpornography/ or (http://www.nybooks/articles/13790) - Access. 08. Dec. 2011.

FINLEY, M.I. O Legado da Grécia - Uma Nova Avaliação. Brasília. Editora Universidade de Brasília, 1998.

GUIMARÃES, Guilherme F. A. Cintra. O Uso Criativo dos Paradoxos do Direito na Aplicação dos Princípios Constitucionais: Abertura, Autoritarismo e Pragmatismo na Jurisdição Constitucional Brasileira. UnB, 2007.

KUSHNIR, Beatriz. Cães de Guarda - Jornalistas e censores, do AI-5 à Constituição de 1988. São Paulo. Boitempo editorial, $1^{a}$ edição. 2004.

LUHMANN, Niklas. The differenciation of society. Trad. de Stephen Holmes e Charles Larmore. New York: Columbia University Press, 1982;

A Realidade dos Meios de Comunicação. Trad. Ciro Marcondes Filho. São Paulo. Editora Paulus, 2005.

Sociologia do direito I e II. Trad. Gustavo Bayer. Rio de Janeiro: Tempo Brasileiro, 1983 e 1985;

A Constituição como aquisição evolutiva. Trad. de Menelick de Carvalho Netto (para fins acadêmicos). In: ZAGREBELSKY, Gustavo, PORTINARO, Píer Paolo, LUTHER, Jörg (Orgs.). Il Futuro della Constituzione. Torino: Einaudi, 1996.

Social Systems. Translated by John Bednarz, Jr. with Dirk Baecker.Stanford University Press, Stanford California, 1995.

MARQUES, Andréa Neves Gonzaga. Liberdade de Expressão e a Colisão entre Direitos Fundamentais. Sérgio Antônio Fabris Editor. Porto Alegre. 2010.

MENDES, Gilmar. Colisão de Direitos Fundamentais: Liberdade de Expressão e de Comunicação e Direito à Honra e à Imagem. Revista dos Tribunais, $\mathrm{n}^{\circ} 5$ out/dez de 1993, p. 16-20. 
COELHO, Inocêncio. BRANCO, Paulo Gustavo. Curso de Direito

Constitucional. São Paulo: Editora Saraiva, 2008 - 2ª Edição.

NEGRI, Antonio. O Poder Constituinte: ensaio sobre as alternativas da modernidade. Editora DP \& A - De Paulo Editora Ltda, 2002.

NETTO, M. C. A Hermenêutica Constitucional e os Desafios Postos aos Direitos Fundamentais.

; SCOTTI, Guilherme. Os direitos fundamentais e a (in)certeza do direito: a produtividade das tensões principiológicas e a superação do sistema de regras. Belo Horizonte: Editora Fórum, 2011.

NEVES, Marcelo. Transconstitucionalismo. São Paulo. Editora Martins Fontes, $1^{\mathrm{a}}$ edição. 2009.

Entre Têmis e Leviatã: uma relação difícil: o Estado democrático de direito a partir e além de Luhmann e Habermas. São Paulo: Martins Fontes, 2006.

PAIXÃO, Cristiano. Modernidade, tempo e direito. Belo Horizonte: Del Rey, 2002.

; BIGLIAZZI, Renato. História Constitucional Inglesa e norteamericana: do surgimento à estabilização da forma constitucional. Brasília: Editora UnB, 2008.

MAIA, Paulo Sávio Peixoto. História da Constituição como história conceitual: Marbury v. Madison e o surgimento da supremacia constitucional. Revista Acadêmica - Faculdade de Direito do Recife, v. LXXXI, p. 156-175, 2009.

NETTO, M. C. Entre permanência e mudança: reflexões sobre o conceito de constituição. In: MOLINARO, Carlos Alberto; MILHORANZA, Mariângela Guerreiro; PORTO, Sérgio Gilberto. (Org.). Constituição, jurisdição e processo -- estudos em homenagem aos 55 anos da Revista Jurídica. $1^{\text {a }}$ ed. Sapucaia do Sul - RS: Notadez, 2007, p. 97-109.

Entre passado e futuro: os desafios postos à afirmação dos direitos sociais e os 20 anos da Constituição da República. In: CORDEIRO, Juliana V; CAIXETA, Sebastião V.. (Org.). Vinte anos da Constituição Cidadã. $1^{a}$ ed. São Paulo: LTr, 2009, v. 1, p. 19-36. 
ROMÃO, José Eduardo Elias. Pedra na Funda: a classificação indicativa contra a indústria da comunicação. UnB, 2010.

SARMENTO, Daniel. Estudos de Direito Constitucional. Rio de Janeiro: Editora Lumen Juris, 2010.

SILVA, José Afonso da. Ordenação Constitucional da Cultura. Ed Malheiros. São Paulo. 2001.

SUANZES-CARPEGNA, Joaquín Varela. Algumas reflexões metodológicas sobre a história constitucional. In: Revista IHGB, Rio de Janeiro, jul./set. 2008.

TOULMIN, Stephen. Os usos do argumento. Tradução: Reinaldo Guarany. São Paulo: Martins Fontes, 2001.

VERSCHRAEGEN, Gert. Humans Rights and Modern Society: A Sociological Analysis from the Perspective os Systems Theory. Jornal o Law ans Society. Volume 29, Number 2, June 2002. Pp. 258-81. 